\title{
Effect of storage temperature during transport of ovaries on in vitro embryo production in Iberian red deer (Cervus elaphus hispanicus)
}

\author{
O. García-Álvarez ${ }^{\mathrm{a}}$, A. Maroto-Morales ${ }^{\mathrm{b}}$, F. Berlinguer ${ }^{\mathrm{c}}$, M.R. Fernández-Santos ${ }^{\mathrm{b}, \mathrm{d}}$, \\ M.C. Esteso ${ }^{\mathrm{e}}$, P. Mermillod ${ }^{\mathrm{f}}$, J.A. Ortiz ${ }^{\mathrm{g}}$, M. Ramon ${ }^{\mathrm{b}}$, M.D. Pérez-Guzmán ${ }^{\mathrm{a}}$, \\ J.J. Garde ${ }^{\mathrm{b}, \mathrm{d}}$, A.J. Soler ${ }^{\mathrm{a}, \mathrm{b}, *}$ \\ ${ }^{a}$ Regional Center of Animal Selection and Reproduction (CERSYRA) JCCM, 13300 Valdepeñas, Spain \\ ${ }^{\mathrm{b}}$ Biology of Reproduction Group, National Wildlife Research Institute (IREC) UCLM-CSIC-JCCM, 02071 Albacete, Spain \\ ${ }^{\mathrm{c}}$ Department of Animal Biology, University of Sassari, Sassari, Italy \\ ${ }^{\mathrm{d}}$ Institute of Regional Development (IDR) UCLM, 02071 Albacete \\ ${ }^{\mathrm{e}}$ Animal Reproduction and Obstretic, University of León, 24071 León, Spain \\ ${ }^{\mathrm{f}}$ INRA, UMR85, Physiologie de la Reproduction et des Comportements, Nouzilly, France \\ ${ }^{\mathrm{g}}$ Medianilla S.L. Finca Las Lomas, Vejer de la Frontera (Cádiz)
}

Received 15 November 2009; received in revised form 12 July 2010; accepted 18 July 2010

\begin{abstract}
The aim of this work was to study the effect of storage temperature during the transport of ovaries on cleavage and blastocyst rates in Iberian red deer, because wild populations of this subspecies are usually far from laboratories. A total of 472 ovaries from 236 Iberian hinds were recovered and maintained in saline solution at $5-8{ }^{\circ} \mathrm{C}$ or $20-25{ }^{\circ} \mathrm{C}$ for $12 \mathrm{~h}$. After storage, aspirated oocytes were matured with FSH/LH or EGF and the developed embryos were cultured with oviduct epithelial cells monolayer $(\mathrm{OCM})$. A higher $(\mathrm{P}=0.009)$ cleavage rate was obtained when the ovaries were stored at $5-8{ }^{\circ} \mathrm{C}$. However, there were no differences between both storage temperatures in relation to the percentage of blastocysts obtained. Considering the management and production systems of Iberian red deer, this study provides important information about the ovary storage temperature during transport with the purpose of assuring an optimal in vitro embryo production.
\end{abstract}

(C) 2010 Elsevier Inc. All rights reserved.

Keywords: Iberian red deer; Ovary storage; In vitro fertilization

\section{Introduction}

The use of assisted reproduction technologies (ART) ensures the continuity and the genetic variability of the breeds, populations and species [1-3]. The collection of

\footnotetext{
* Corresponding author. Tel: +34 967599200; fax: +34 967599238

E-mail address: anajosefa.soler@uclm.es (A.J. Soler).
}

sperm samples, oocytes and embryos is an aspect of great importance in the development of these technologies. However, for wild species there are many drawbacks in relation to sample collection.

The Iberian red deer (Cervus elaphus hispanicus) is a wild subspecies of red deer that inhabit Spain and Portugal. The main appeal of this subspecies is its trophy, so the embryo production focused on achieving individuals with higher quality of trophy from hunted 
animals is an important goal. Nowadays, there is a remarkable interest in the use of ART for the management of Iberian red deer populations. Most of the technologies carried out in this specie have been related with the collection, storage and subsequent application of spermatozoa by means of artificial insemination [4-16]. However, in vitro embryos have not yet been produced so far. That could be due to the difficulty in obtaining the Iberian hind oocytes. For the in vivo oocyte collection, specific installations in farms are needed and in Spain there are no many private properties with these characteristics since the production of this cervid subspecies is mainly extensive. In such cases, oocyte collection from ovaries of hunted hinds offers an opportunity to obtain valuable genotypes. It is important to mention that many variables may adversely affect oocyte quality and subsequent embryo development such as temperature and time of ovary storage.

Under field conditions it is not always possible to collect and immediately transport the ovaries from Iberian hinds to the laboratory due to a lack of technicians and equipment. In addition, most Iberian red deer wild populations are far from laboratories. For these reasons, we have decided to study in depth some of the aspects that could affect the oocyte quality during the transportation, such as the ovary storage temperature.

It is known that the metabolic activities of cells are slowed down or completely arrested at low temperatures, whereas cellular autolysis could occur in ovaries during the long period of transportation at high temperatures [3]. Many authors have reported, in several species, that ovary storage at $38{ }^{\circ} \mathrm{C}$ for several hours decreased the rate of blastocyst formation $[17,18]$. Ovary storage at low temperatures in bovine and feline species did not show any effect on oocyte maturation or on the potential of oocytes to develop into blasctocysts $[19,20]$. However, oocytes from equine, porcine and canine were more sensitive at low temperatures [21-23].

With this background, the objective of this study was to test two ovary storage temperatures $\left(5-8^{\circ} \mathrm{C} v s\right.$. $20-25{ }^{\circ} \mathrm{C}$ ) easily to obtain and maintain for $12 \mathrm{~h}$ in order to identify the field conditions that better preserve oocyte development competence and subsequent embryo development.

\section{Materials and methods}

All chemicals and media were from Sigma (Madrid, Spain). Biladyl ${ }^{\circledR}$ and Triladyl ${ }^{\circledR}$ were from Minituib (Germany). Estrus sheep serum (ESS) was collected from sheep in oestrus and heat inactivated at $56{ }^{\circ} \mathrm{C}$ for $45 \mathrm{~min}$.

\subsection{Oocyte collection and maturation}

A total of 472 ovaries were collected from 236 Iberian hinds selectively hunted and eviscerated in an authorized place in their natural habitat (game reserve) at the beginning of the hunting season (SeptemberOctober). Collection of ovaries was carried out in two successive days. Ovaries were placed into glass containers with saline solution and transported to the laboratory at different temperatures according to the experimental design within $12 \mathrm{~h}$ after being removed. From each hind, one ovary was stored at $5-8{ }^{\circ} \mathrm{C}$ and the other one at room temperature $\left(20-25{ }^{\circ} \mathrm{C}\right)$. Containers were transported into expanded polystyrene boxes with cold accumulators for the $5-8{ }^{\circ} \mathrm{C}$ treatment. In both treatments, immature oocytes were aspirated from 2 to $6 \mathrm{~mm}$ follicles using a 19 gauge needle connected to a $5 \mathrm{~mL}$ syringe containing $0.5 \mathrm{~mL}$ of TCM 199 supplemented with Hepes $(2.38 \mathrm{mg} / \mathrm{mL})$, heparin and gentamycin $(40 \mu \mathrm{g} / \mathrm{mL})$. Aspirated cumulus oocytes complexes (COCs) were washed in TCM 199-gentamycin, and those with dark homogeneous cytoplasm and surrounded by tightly packed cumulus cells were selected and randomly placed in four-well plates containing $500 \mu \mathrm{L}$ of TCM 199 supplemented with cysteamine $(100 \mu \mathrm{M}), 10 \%$ fetal calf serum (FCS) and FSH/LH $(10 \mu \mathrm{g} / \mathrm{mL})$ or EGF $(10 \mathrm{ng} / \mathrm{mL})$, and matured at $38.5^{\circ} \mathrm{C}$ under a humidified atmosphere of $5 \% \mathrm{CO}_{2}$ in air for $24 \mathrm{~h}$.

\subsection{In vitro fertilization}

After $24 \mathrm{~h}, \mathrm{COCs}$ were washed in order to remove cumulus cells by gentle pipeting. Then the oocytes were transferred into four-well plates containing 450 $\mu \mathrm{L}$ of synthetic oviduct fluid as described by Berg and Asher [24] for red deer (IVF-SOF) with 20\% ESS.

For IVF, epididymal spermatozoa from one male frozen with Triladyl ${ }^{\circledR}$ as described by Soler et al [4] were used. Thawed epididymal spermatozoa were selected by centrifugation on a Percoll ${ }^{\circledR}$ gradient (45/ $90 \%$ ). The sperm pellet was diluted to $10 \times 10^{6}$ spermatozoa/mL in IVF-SOF with $20 \%$ ESS and incubated at $38.5{ }^{\circ} \mathrm{C}$ in $5 \% \mathrm{CO}_{2}$ for $10 \mathrm{~min}$. Spermatozoa were co-incubated with the oocytes at a final concentration of $10^{6}$ spermatozoa/mL for $18 \mathrm{~h}$ at $38.5^{\circ} \mathrm{C}$ in $5 \% \mathrm{CO}_{2}, 5 \%$ $\mathrm{O}_{2}$ and $90 \% \mathrm{~N}_{2}$ humidified atmosphere.

\subsection{In vitro culture}

Presumptive zygotes were washed with SOF-BSA [25] and cultured with SOF-BSA supplemented with $10 \%$ FCS in the presence of cow oviduct epithelial cells 
monolayer (OCM) at $38.5^{\circ} \mathrm{C}$ under a humidified atmosphere of $5 \% \mathrm{CO}_{2}$ in air for 8 days Half of the culture medium $(250 \mu \mathrm{L})$ was renewed (fresh medium) every $48 \mathrm{~h}$ during in vitro development.

Cleavage rate was assessed at 24 and 48 hours post insemination (hpi) and the embryo rate reaching blastocyst stage was assessed at 8 days post insemination (dpi) by phase-contrast optic. At this time, blastocysts were stained with Hoechst 33342 (Fig. 1).

\subsection{Preparation of oviduct epithelial cells monolayer}

Ipsilateral cow oviduct to the ovary bearing a corpus haemorragicum was collected at local slaughterhouse one week before ovary collection and dissected free from surrounding tissues. After several washing of the oviduct, the mucosa was expelled by gentle squeezing using a sterile glass slide along the outside of the oviduct, from the uterotubal junction to the infundibulum on a Petri dish. Resulting epithelium fragments were washed three times by consecutive suspensions and centrifugations $(500 \times \mathrm{g}$ for $5 \mathrm{~min})$ in TCM-199 medium and cultured in four-well plates containing $500 \mu \mathrm{L}$ of TCM-199 supplemented with $10 \%$ FCS and $40 \mu \mathrm{g} / \mathrm{mL}$ gentamycin. Cells were cultured at $38.5{ }^{\circ} \mathrm{C}$ under a humidified atmosphere of $5 \% \mathrm{CO}_{2}$ in air. Fragments spontaneously formed vesicles after
(A)

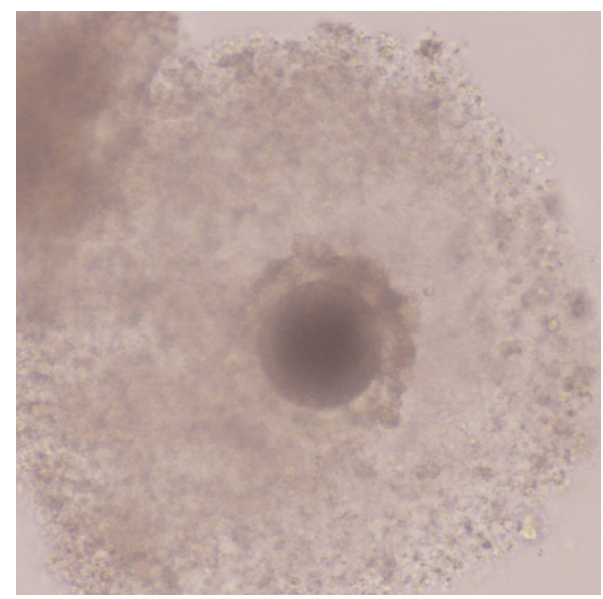

(C)

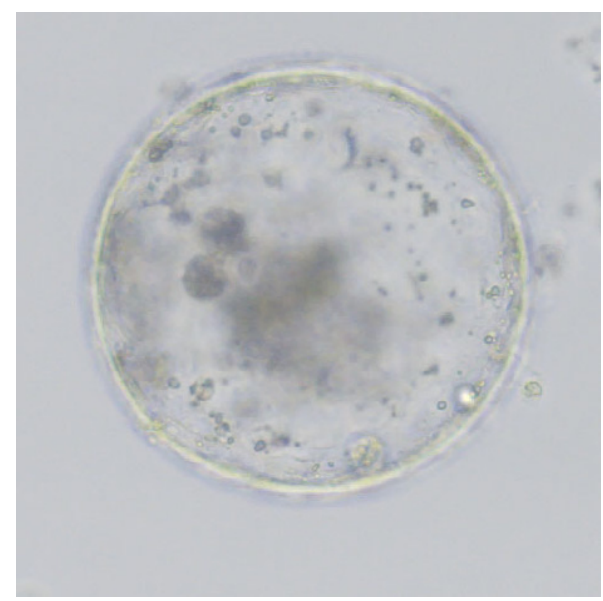

(B)

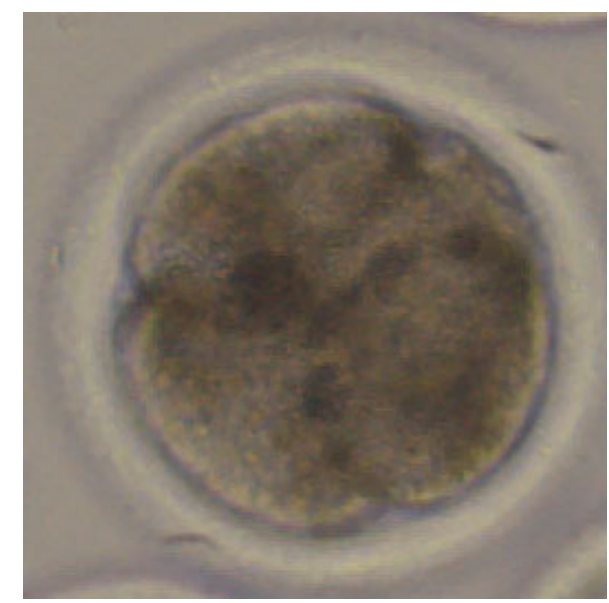

(D)

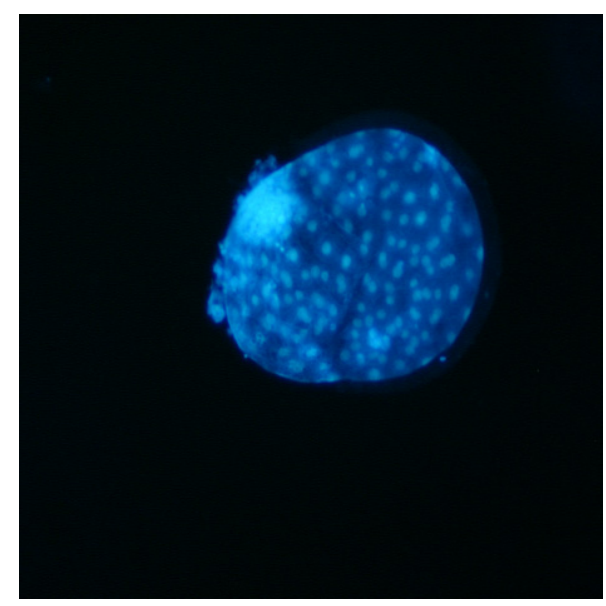

Fig. 1. Oocytes aspirated from post-mortem ovaries and embryos obtained after in vitro maturation, fertilization and culture in Iberian red deer. (A) Oocytes with cumulus cells expanded after in vitro maturation; (B and C) 4-cell embryo and blastocyst after in vitro fertilization and culture examined by phase-contrast optics after 48 hpi and 8 dpi, respectively; (D) Blastocyst stage embryo after staining with Hoechst 33342 and examined under fluorescence microscope after $8 \mathrm{dpi}$. 
2-3 days of culture. These vesicles formed monolayers within 7 days after initiation of the culture. Medium was renewed every $48 \mathrm{~h}$ and replaced $24 \mathrm{~h}$ before culture of zygotes by SOF-BSA supplemented with $10 \%$ FCS.

\subsection{In vitro fertilization in ovine}

Due to the practical limitations cited above in relation to the location of deer game reserves, ovary storage at $30-35{ }^{\circ} \mathrm{C}$ for a short time was not a possible alternative for study. For this reason, an additional trial in a domestic species (ovine), in which it is accepted that the optimal temperature of ovary storage is $30-35{ }^{\circ} \mathrm{C}$ [26-28], was carried out as a way to provide extra information about how oocyte competence and embryo development is affected by storage methods. Thus, we decided to include an additional experiment in which the two storage conditions considered in the deer's work $\left(5-8{ }^{\circ} \mathrm{C}\right.$ and $20-25{ }^{\circ} \mathrm{C}$ for $12 \mathrm{~h}$ ) were compared with a storage treatment at $30-35{ }^{\circ} \mathrm{C}$ for $4 \mathrm{~h}$ (Control). This temperature could be maintained with a portable incubator.

From each ewe, one ovary was fixed to Control treatment and the other one simultaneously to $20-25{ }^{\circ} \mathrm{C}$ or $5-8{ }^{\circ} \mathrm{C}$ treatments. Ovaries of all treatments (Control, $22-25{ }^{\circ} \mathrm{C}$ and $5-8{ }^{\circ} \mathrm{C}$ ) were sliced using a micro-blade and the follicle content released in medium TCM-199 supplemented with Hepes $(2.38 \mathrm{mg} / \mathrm{mL})$, heparin and gentamycin $(40 \mu \mathrm{g} / \mathrm{mL})$. Aspirated cumulus oocytes complexes (COCs) were handled in the same way as the deer assay and matured in $500 \mu \mathrm{L}$ of TCM 199 supplemented with cysteamine $(100 \mu \mathrm{M}), 10 \%$ fetal calf serum (FCS) and FSH/LH $(10 \mu \mathrm{g} / \mathrm{mL})$ at $38.5^{\circ} \mathrm{C}$ under a humidified atmosphere of $5 \% \mathrm{CO}_{2}$ in air for $24 \mathrm{~h}$. After $24 \mathrm{~h}, \mathrm{COCs}$ were washed in order to remove cumulus cells by gentle pipeting and transferred into four-well plates containing $450 \mu \mathrm{L}$ of synthetic oviduct fluid (SOF) as described by Cognie et al [29] with $10 \%$ ESS.

Ram sperm samples used in the in vitro fertilization were frozen with Biladyl ${ }^{\circledR}$ as described by GarcíaÁlvarez et al [30] and selected as it was above described. Spermatozoa were co-incubated with the oocytes at a final concentration of $10^{6}$ spermatozoa $/ \mathrm{mL}$ for $18 \mathrm{~h}$ at $38.5{ }^{\circ} \mathrm{C}$ in $5 \% \mathrm{CO}_{2}, 5 \% \mathrm{O}_{2}$ and $90 \% \mathrm{~N}_{2}$ humidified atmosphere.

Presumptive zygotes were cultured in SOF enriched with amino acids and BSA [31] for 8 days at $38.5^{\circ} \mathrm{C}$ in $5 \% \mathrm{CO}_{2}, 5 \% \mathrm{O}_{2}$ and $90 \% \mathrm{~N}_{2}$ humidified atmosphere. Cleavage rate was assessed at 40-44 hpi and the embryo rate reaching blastocyst stage was assessed at 8 dpi by phase-contrast optic. This trial was replicated three times.

We also carried out another assay in ovine to assure that the resumption meiotic, as a result of loss of follicular regulation, had not been initiated. Ovaries were stored at $30{ }^{\circ} \mathrm{C}$ for $4 \mathrm{~h}$ (Control), or at $20-22{ }^{\circ} \mathrm{C}$ and $5-8{ }^{\circ} \mathrm{C}$ for $12 \mathrm{~h}$. After that, oocytes were recovered in TCM-199 supplemented with Hepes (2.38 mg/mL), heparin and gentamycin $(40 \mu \mathrm{g} / \mathrm{mL})$ and washed in TCM-119-gentamycin. Finally, the oocytes were denuded of cumulus cells by pipetting in D-PBS containing $0.1 \%(\mathrm{w} / \mathrm{v})$ hyaluronidase. Oocytes denuded (20-25 per treatment) were stained with Hoechst 33342 and the chromatin status in the germinal vesicle (GV) or germinal vesicle breakdown (GVBD) was recorded.

\subsection{Statistical analysis}

Statistical analyses were carried out using SPSS ${ }^{\circledR}$, version 15 (SPSS Inc., Chicago, IL, USA). A mixed effects model including the storage temperature $\left(5-8{ }^{\circ} \mathrm{C} v s\right.$. $20-25^{\circ} \mathrm{C}$ ) and maturation media (FSH/LH vs EGF) as fixed factors and the day of ovary collection as random effect was carried out to study the consequences of storage temperature on cleavage rate at 24 and $48 \mathrm{hpi}$ and on the percentage of blastocysts obtained at $8 \mathrm{dpi}$ over total and cleaved oocytes in Iberian red deer. Since no significant differences $(\mathrm{P}<0.05)$ were found between both maturation media, results for this factor were not showed.

For the additional experiment using ovine data, a mixed effects model including the storage temperature (Control, $5-8{ }^{\circ} \mathrm{C}$ and $20-25^{\circ} \mathrm{C}$ ) as fixed factor and the day of ovary collection as random effect was also carried out to test the effects of storage temperature on cleavage rate at 40-44 hpi and on the percentage of blastocysts obtained at 8 dpi over total and cleaved oocytes.

Comparison of means was carried out using the Bonferroni test. Differences were considered statistically significant at $\mathrm{P}<0.05$. The data are expressed as means \pm SEM.

\section{Results}

As shown in Table 1, the storage temperature only affected the cleavage rate at 48 hpi with significantly higher results when the hind ovaries were stored at $5-8{ }^{\circ} \mathrm{C}$ in relation to $20-25{ }^{\circ} \mathrm{C}(78.19 \%$ vs. $64.90 \%, \mathrm{P}=$ 0.009). However, the percentage of blastocysts ob- 
Table 1

Effect of ovary storage temperature on cleavage and blastocyst rate in Iberian red deer

\begin{tabular}{|c|c|c|c|c|}
\hline \multirow[t]{2}{*}{ Storage temperature } & \multirow[t]{2}{*}{ No. Cleaved embryo at 24 hpi (\%) } & \multirow[t]{2}{*}{ No. Cleaved embryo at $48 \mathrm{hpi}(\%)$} & \multicolumn{2}{|c|}{ No. Blastocyst at 8 dpi (\%) } \\
\hline & & & Total & Cleaved \\
\hline $20-25^{\circ} \mathrm{C}$ & $23(14.23 \pm 2.60)$ & $50(64.90 \pm 2.96)$ & $7(9.61 \pm 2.36)$ & $(13.88 \pm 3.70)$ \\
\hline $5-8{ }^{\circ} \mathrm{C}$ & $20(20.80 \pm 5.08)$ & $38(78.19 \pm 1.85)$ & $8(17.71 \pm 6.64)$ & $(20.61 \pm 8.01)$ \\
\hline$P$ value & 0.294 & 0.009 & 0.295 & 0.475 \\
\hline
\end{tabular}

Data are Mean \pm SEM. Significant differences were considered within the same column when $\mathrm{P}$ value was $<0.05$

tained was not significantly different between both storage temperatures (Table 1).

In the experiment with ovine, the cleavage rate for the oocytes collected from ovaries stored at $5-8{ }^{\circ} \mathrm{C}$ was significantly lower $(23 \%)$ in relation to Control and $20-25{ }^{\circ} \mathrm{C}$ treatments $(47 \%$ and $43 \%$, respectively; Table 2). However, there were no significant differences between treatments in relation to the percentage of blastocysts obtained (Table 2). On the other hand, chromatin of all the stained oocytes from Control and $20-25^{\circ} \mathrm{C}$ treatments were in GV stage but, only a $91 \%$ was in this stage for the ovaries stored at $5-8{ }^{\circ} \mathrm{C}$.

\section{Discussion}

The production of Iberian red deer under extensive conditions together with long distances to laboratories involves problems in relation to the biological sample collection (testis and ovaries) and transport. Studies aimed to show the viability of different cells depending on storage conditions, just as storage temperature, are needed in order to establish which conditions are optimal in this cervid subspecies. Several authors have carried out works about the influence of testis storage time at $5{ }^{\circ} \mathrm{C}$ on the sperm quality in Iberian red deer [32-34], but no studies on the effects of ovary storage conditions on in vitro embryo production were found on the literature. Thus, the evaluation of different temperatures during the ovary storage, easily to obtain under the particular conditions of the Iberian red deer production system, will allow us to identify which of them preserve better the quality of the biological samples (oocytes).
Red deer embryos have been produced in vitro with variable results between different authors getting blastocyst rates around a $15 \%$ according to experimental design [24,35-39]. In those studies, ovaries collected postmortem were stored at temperatures between $30{ }^{\circ} \mathrm{C}$ and $35^{\circ} \mathrm{C}$ and they were transported to the laboratory in 3 hours after slaughter, approximately. In this work, hind ovaries were stored at two temperatures easy to obtain (room temperature: $20-25^{\circ} \mathrm{C}$ and a refrigeration temperature: $5-8{ }^{\circ} \mathrm{C}$ ). We could not include an ovary storage treatment at $30-35{ }^{\circ} \mathrm{C}$ for short time since the distance from deer wild populations to laboratory was long (it takes around $12 \mathrm{~h}$ ). In addition, a temperature around $30-35{ }^{\circ} \mathrm{C}$ could be difficult to maintain under field conditions.

In our study, it was possible to obtain embryos from stored ovary's oocytes for $12 \mathrm{~h}$ at $5-8{ }^{\circ} \mathrm{C}$, with even higher results of cleavage rate at $48 \mathrm{~h}$ for this storage temperature in comparison with room temperature (20-25 $\left.{ }^{\circ} \mathrm{C}\right)$, although blastocyst rate was similar in both treatments. According to our results, Matsusthita et al [19] reported that ovary storage temperature $\left(10^{\circ} \mathrm{C} v s\right.$. $30{ }^{\circ} \mathrm{C}$ ) had no effect on oocyte developmental competence in bovine. Moreover, ovary transport at low temperatures had a positive effect on the oocyte maturation rates in feline [20] and canine [40] species. In opposite, for other species, ovary transport at high temperatures was more advantageous with higher matured oocyte and embryo rates, such as equine [21] and porcine [22] species.

Because we could not include an ovary storage treatment at $30-35{ }^{\circ} \mathrm{C}$ for a short time in red deer, we carried out an additional trial in a domestic species

Table 2

Effect of ovary storage temperature on cleavage and blastocyst rate in ovine

\begin{tabular}{cccc}
\hline Storage temperature & No. Cleaved embryo at 40-44 hpi (\%) & \multicolumn{2}{c}{ No. Blastocyst at 8 dpi $(\%)$} \\
\cline { 2 - 4 } & & Total & Cleaved \\
\hline Control & $67(47.70 \pm 0.72)^{\mathrm{a}}$ & $23(19.00 \pm 7.21)^{\mathrm{a}}$ & $(38.33 \pm 13.96)^{\mathrm{a}}$ \\
$20-25^{\circ} \mathrm{C}$ & $55(43.50 \pm 10.25)^{\mathrm{a}}$ & $16(16.00 \pm 2.08)^{\mathrm{a}}$ & $(33.67 \pm 0.66)^{\mathrm{a}}$ \\
$5-8{ }^{\circ} \mathrm{C}$ & $31(23.17 \pm 3.49)^{\mathrm{b}}$ & $8(5.17 \pm 3.03)^{\mathrm{a}}$ & $(17.33 \pm 10.10)^{\mathrm{a}}$ \\
\hline
\end{tabular}

Data are Mean \pm SEM. Different letters within the same column are statistically different $(\mathrm{P}<0.05)$. 
(ovine). This trial was done with the purpose of providing additional information about how competency of oocytes is affected by the storage temperature. We found significant differences between treatments for the cleavage rate, which was lower when sheep ovaries were stored at low temperatures $\left(5-8{ }^{\circ} \mathrm{C}\right)$, than for the storage at $20-25{ }^{\circ} \mathrm{C}$ and for the Control treatment. In relation to the blastocyst rate, no significant differences were observed among treatments. It is possible that the oocytes from ovine species are more sensitive against low temperatures than those from the cervid. Our data also showed that both cleavage and blastocyst rates were similar for the $20-25{ }^{\circ} \mathrm{C}$ and the Control treatment. It is possible that the same event happens in the Iberian red deer when the ovaries are stored at $30-35{ }^{\circ} \mathrm{C}$ for $4 \mathrm{~h}$ or $20-25{ }^{\circ} \mathrm{C}$ for $12 \mathrm{~h}$.

It is known that when the oocytes are maintained in meiotic arrest at the GV stage for a time, they have the opportunity to acquire greater developmental competence in vitro [41]. As was pointed out by Blondin et al [42], one way to achieve greater developmental competence was to maintain the oocytes within the follicle for a time after slaughter and before fertilization. In our experiment with ewes, we found that when ovaries were stored at $30-35{ }^{\circ} \mathrm{C}$ for $4 \mathrm{~h}$ or at $20-22{ }^{\circ} \mathrm{C}$ for $12 \mathrm{~h}$, the meiotic resumption was not initiated in the oocytes, due to the fact that the chromatin of all of them was at GV stage. However, for the cold storage treatment $\left(5-8{ }^{\circ} \mathrm{C}\right.$ for $12 \mathrm{~h}$ ) only $91 \%$ of oocytes were in the GV stage. Moreover, for this treatment both cleavage and blastocyst rates were lower than for the other treatments, suggesting that in ovine species a prolonged exposure of ovaries to cold temperatures before oocyte collection could have a negative effect on the developmental competence of embryos. These results are in accordance with those by Moor and Crosby [43] who found that, in ovine, the exposure of oocytes to low temperatures induces chromosomal abnormalities and, as a consequence, a decrease in the development to expanded blastocyst.

In conclusion, our results showed that for in vitro embryo production in Iberian red deer, when the ovary storage time is long (about $12 \mathrm{~h}$ ), no differences were found for the percentage of blastocyst obtained when the ovaries were transported at low temperatures $\left(5-8^{\circ} \mathrm{C}\right)$ or at room temperature $\left(20-25{ }^{\circ} \mathrm{C}\right)$. Taking into account our results, we would choose $20-25{ }^{\circ} \mathrm{C}$ as an optimal ovary storage temperature during a long period of storage.

\section{Acknowledgments}

This work was supported by Spanish Ministry of Education and Science (AGL2007-60271GAN). The authors thank Medianilla S.L. for their collaboration in the collection of the ovaries used in this work. Olga García-Álvarez and Alejandro Maroto Morales were recipients of scholarships from INIA and JCCM, respectively. Milagros C. Esteso was supported by the Juan de la Cierva Program from Spanish Ministry of Education and Science.

\section{References}

[1] Gilmore JA, McGann LE, Ashworth E, Acker JP, Raath JP, Bush M, Critser JK. Fundamental cryobiology of selected African mammalian spermatozoa and its role in biodiversity preservation through the development of genome resource banking. Anim Reprod Sci 1998;53:277-97.

[2] Holt WV, Abaigar T, Jabbour HN. Oestrous synchronization, semen preservation and artificial insemination in the Mohor gazelle (Gazella dama mhorr) for the establishment of a genome resource bank programme. Reprod Fertil Dev 1996;8: 1215-22.

[3] Holt WV, Pickard AR. Role of reproductive technologies and genetic resource banks in animal conservation. Rev Reprod 1999;4:143-50.

[4] Soler AJ, García AJ, Fernández-Santos MR, Esteso MC, Garde JJ. Effects of thawing procedure on postthawed in vitro viability and in vivo fertility of red deer epididymal spermatozoa cryopreserved at $-196{ }^{\circ} \mathrm{C}$. J Androl 2003;24:746-56.

[5] Fernández-Santos MR, Esteso MC, Soler AJ, Montoro V, Garde JJ. The effect of different cryoprotectants and the temperatura of addition on the survival of red deer epididymal spermatozoa. Cryo Letters 2005;26:25-32.

[6] Martínez-Pastor F, Martínez F, García-Macías V, Esteso MC, Anel E, Fernández-Santos MR, Soler AJ, de Paz P, Garde J, Anel L. A pilot study on post-thawing quality of Iberian red deer spermatozoa (epididymal and electroejaculated) depending on glycerol concentration and extender osmolality. Theriogenology 2006;66:1165-72.

[7] Martínez-Pastor F, Anel L, Guerra C, Alvarez M, Soler AJ, Garde JJ, Chamorro C, de Paz P. Seminal plasma improves cryopreservation of Iberian red deer epididymal sperm. Theriogenology 2006;66:1847-56.

[8] Fernández-Santos MR, Esteso MC, Montoro V, Soler AJ, Garde JJ. Influence of various permeanting cryoprotectants on freezability of Iberian red deer (Cervus elaphus hispanicus) epididymal spermatozoa: effects of concentration and temperature of addition. J Androl 2006;27:734-45.

[9] Fernández-Santos MR, Esteso MC, Montoro V, Soler AJ, Garde JJ. Cryopreservation of Iberian red deer (Cervus elaphus hispanicus) epididymal spermatozoa: effects of egg yola, glycerol and cooling rate. Theriogenology 2006;66:1931-42.

[10] Fernández-Santos MR, Esteso MC, Soler AJ, Montoro V, Garde JJ. Effects of egg yolk and cooling rate on the survival of refrigerated red deer (Cervus elaphus hispanicus) epididymal spermatozoa. Reprod Dom Anim 2006;41:114-8. 
[11] Fernández-Santos MR, Martínez-Pastor F, García-Macías V, Esteso MC, Soler AJ, de Paz P, Anel L, Garde JJ. Sperm characteristics and DNA integrity of Iberian red deer (Cervus elaphus hispanicus) epididymal spermatozoa frozen in the presence of enzymatic and nonenzymatic antioxidant. J Androl 2007;28:294-305.

[12] Fernández-Santos MR, Martínez-Pastor F, García-Macías V, Esteso MC, Soler AJ, de Paz P, Anel L, Garde JJ. Extender osmolality and sugar supplementation exert a complex effect on the cryopreservation of Iberian red deer (Cervus elaphus hispanicus) epididymal spermatozoa. Theriogenology 2007;67: 738-53.

[13] Martínez-Pastor F, Martínez F, Álvarez M, Maroto-Morales A, García-Álvarez O, Soler AJ, Garde JJ, de Paz P, Anel L. Cryopreservation of Iberian red deer (Cervus elaphus hispanicus) spermatozoa obtained by electroejaculation. Theriogenology 2009;71:628-38.

[14] Garde JJ, Martínez-Pastor F, Gomendio M, Malo AF, Soler AJ, Fernández-Santos MR, Esteso MC, García AJ, Anel L, Roldán ER. The application of reproductive technologies to natural populations of red deer. Reprod Domest Anim 2006;41:93-102.

[15] Gomendio M, Malo AF, Soler AJ, Fernandez-Santos MR, Esteso MC, Garcia AJ, Roldan ER, Garde JJ. Male fertility and sex ratio at birth in red deer. Science 2006;314:1445-7.

[16] Malo AF, Garde JJ, Soler AJ, Garcia AJ, Gomendio M, Roldan ER. Male fertility in natural populations of red deer is determined by sperm velocity and the proportion of normal spermatozoa. Biol Reprod 2005;72:822-9.

[17] Yang NS, Lu KH, Gordon I. In vitro fertilization (IVF) and culture (IVC) of bovine oocytes from stored ovaries. Theriogenology 1990;33:352.

[18] Nakao H, Nakatsuji N. Effect of storage conditions of bovine ovaries and oocytes on the success rate of in vitro fertilization and culture. J Reprod Dev 1992;38:11-3.

[19] Matsushita S, Tani T, Kato Y, Tsunoda Y. Effect of lowtemperature bovine ovary storage on the maturation rate and developmental potential of follicular oocytes after in vitro fertilization, parthenogenetic activation, or somatic cell nucleus transfer. Anim Reprod Sci 2004;84:293-301.

[20] Naoi H, Otoi T, Shimamura T, Karja NW, Agung B, Shimizu R, Taniguchi M, Nagai T. Developmental competence of cat oocytes from ovaries stored at various temperature for $24 \mathrm{~h}$. J Reprod Dev 2007;53:271-7.

[21] Love LB, Choi YH, Love CC, Varner DD, Hinrichs K. Effect of ovary storage and oocyte transport method on maturation rate of horse oocytes. Theriogenology 2003;59:765-74.

[22] Wongsrikeao P, Otoi T, Karja NW, Agung B, Nii M, Nagai T. Effects of ovary storage time and temperature on DNA fragmentation and development of porcine oocytes. J Reprod Dev 2005;51:87-97.

[23] Lee HS, Yin XJ, Kong IK. Sensivity of canine oocytes to low temperature. Theriogenology 2006;66:1468-70.

[24] Berg DK, Asher GW. New developments reproductive technologies in deer. Theriogenology 2003;59:189-205.

[25] Locatelli Y, Cognié Y, Vallet JC, Baril G, Verdier M, Poulin N, Legendre X, Mermillod. Succesful use of oviduct epithelial cell coculture for in vitro production of viable red deer (Cervus elaphus) embryos. Theriogenology 2005;64:1729-39.

[26] Shirazi A, Ostad-Hosseini S, Ahmadi E, Heidari B, ShamsEsfandabadi N. In vitro developmental competence of ICSIderived activated ovine embryos. Theriogenology 2009;71: 342-8.
[27] Shabankareh HK, Zandi M. Developmental potential of sheep oocytes cultured in different maturation media: effects of epidermal growth factor, insulin-like growth factor I, and cysteamine. Fertil Steril 2010;94:335-40.

[28] Wan PC, Hao ZD, Zhou P, Wu Y, Yang L, Cui MS, Liu SR, Zeng SM. Effects of SOF and CR1 media on developmental competence and cell apoptosis of ovine in vitro fertilization embryos. Anim Reprod Sci 2009;114:279-88.

[29] Cognie Y, Poulin N, Locatelli Y, Mermillod P. State-of-theart production, conservation and transfer of in-vitro-produced embryos in small ruminants. Reprod Fertil Dev 2004; 16:437-45.

[30] García-Álvarez O, Maroto-Morales A, Martínez-Pastor F, Garde JJ, Ramón M, Fernández-Santos MR, Esteso MC, PérezGuzmán MD, Soler AJ. Sperm characteristics and in vitro fertilization ability of thawed spermatozoa from Black Manchega ram: electroejaculation and postmortem collection. Theriogenology 2009;72:160-8.

[31] Gardner DK, Lane M, Spitzer A, Batt PA. Enhanced rates of cleavage and development for sheep zygotes cultured to the blastocyst stage in vitro in the absence of serum and somatic cells: amino acids, vitamins, and culturing embryos in groups stimulate development. Biol Reprod 1994;50:390-400.

[32] Soler AJ, Pérez-Guzmán MD, Garde JJ. Storage of red deer epididymides for four days at $5{ }^{\circ} \mathrm{C}$ : effects on sperm motility, viability, and morphological integrity. J Exp Zoolog A Comp Exp Biol 2003;295:188-99.

[33] Soler AJ, Esteso MC, Fernández-Santos MR, Garde JJ. Characteristics of Iberian red deer (Cervus elaphus hispanicus) spermatozoa cryopreserved after storage at $5{ }^{\circ} \mathrm{C}$ in the epididymis for several days. Theriogenology 2005;64:1503-17.

[34] Fernández-Santos MR, Domínguez-Rebolledo AE, Esteso MC, Garde JJ, Martínez-Pastor F. Refrigerated storage of red deer epididymal spermatozoa in the epididymis, diluted and with vitamin C supplementation. Reprod Domest Anim 2009;44: 212-20.

[35] Fukui Y, McGowan LT, James RW, Asher GW, Tervit HR. Effects of culture duration and time of gonadotropin addition on in vitro maturation and fertilization of red deer (Cervus elaphus) oocytes. Theriogenology 1991;35:499-512.

[36] Berg DK, Thompson JG, Asher GW. Development of in vitro embryo production systems for red deer (Cervus elaphus). Part 1. Effect of epithelial oviductal monolayers and heparin on in vitro sperm motility and penetration of in vitro matured oocytes. Anim Reprod Sci 2002;70:65-76.

[37] Berg DK, Thompson JG, Asher GW. Development of in vitro embryo production systems for red deer (Cervus elaphus). Part 2. The timing of in vitro nuclear oocyte maturation. Anim Reprod Sci 2002;70:77-84.

[38] Comizzoli P, Mermillod P, Cognié Y, Chai N, Legendre X, Mauget R. Succesful in vitro production of embryos in the red deer (Cervus elaphus) and the sika deer (Cervus nippon). Theriogenology 2001;55:649-59.

[39] Berg DK, Pugh PA, Thompson JG, Asher GW. Development of in vitro embryo production systems for red deer (Cervus elaphus). Part 3. In vitro fertilisation using sheep serum as a capacitating agent and the subsequent birth of calves. Anim Reprod Sci 2002;70:85-98.

[40] Taş M, Evecen M, Ozdaş OB, Cirit U, Demir K, Birler S, Pabuccuoğlu S. Effect of transport and storage temperature of 
ovaries on in vitro maturation of bitch oocytes. Anim Reprod Sci 2006;96:30-4.

[41] Fouladi Nashta AA, Waddington D, Campbell KHS. Maintenance of bovine oocytes in meiotic arrest and subsequent development in vitro: A comparative evaluation of antral follicle culture with other methods. Biol Reprod 1998;59:255-62.
[42] Blondin P, Coenen K, Guilbault LA, Sirard MA. In vitro production of bovine embryos: Developmental competence is acquired before maturation. Theriogenology 1997;47: 1061-75.

[43] Moor RM, Crosby IM. Temperature-induced abnormalities in sheep oocytes during maturation. J Reprod Fertil 1985;75:467-73. 